\title{
Post office savings and attitude of rural investors in Kerala: A study from Kasaragod district
}

\author{
N. Karunakaran ${ }^{1 *}$, Athira Babu² \\ ${ }^{1} \mathrm{HOD},{ }^{2}$ Post-Graduate Student, ${ }^{\mathbf{1} 2}$ Dept. of Economics, ${ }^{\mathbf{1 , 2}}$ Ek Nayanar Memorial Government College Elerithattu, Kasaragod, Kerala, India \\ *Corresponding Author: N. Karunakaran \\ Email: narankarun@gmail.com
}

\begin{abstract}
Postal saving system provide depositors an access to bank, a safe and convenient method to save money and to promote saving. Investment culture refers to the attitude, awareness and institutions in placing their savings in various financial assets. Post office saving bank is the largest savings institutions in the country which provides numerous benefits to investors. There are a number of attractive schemes, well designed to meet the individual requirements of different investors. It is noted that the study is conducted focusing the attitude of investors on post office saving scheme, various schemes provided through post office, level of satisfaction of investors and amenities in post offices. The investors' attitudes in rural areas have greater significance in formulation of policies for the development and regulations of savings in general and protection and promotion of household investors in particular.
\end{abstract}

Keywords: Post office saving, Attitude, Rural investors, Kerala.

\section{Introduction}

Saving and investment are important for growth. Saving attitude is an essential component in village and Post office saving schemes is one of the modes for them to save their valuable earning. Indian Post Office Schemes helps the people to deposits their money in post office for those who do not have access to bank. Investment is generally associated with the attitude, perception and willingness of individuals and institutions (Karthikeyan, 2011). In India, post office savings scheme provides a secure, risk free and attractive investment options for the small investors and offers the saving products across its 15,5000 post offices. The post office saving bank is included in the union list which provides various scheme framed by the Government. India has been divided into 22 postal circles; each circle headed by a chief postmaster general and is further divided into regions comprising field units headed by a post master general (Aggarwal Ritka, 2012).

Several schemes were offered to serve the investment requirements of the people in rural areas which include: Saving Bank Account, Recurring Deposit Account, Monthly Income Scheme, Time Deposit Account, National Saving Certificate, Public Provident Fund, Senior Citizens Saving Scheme and Sukanya Samriddhi Account (Gupta and Nidhi Gupta, 2012). The strength of Indian post has long tradition of handling financial services in its creditability and trust. In the rural areas people are unable to aware post office saving scheme and many difficulties were faced while depositing money (Parimala Kanthi and Ashok Kumar, 2013). Even today they are not aware of the facilities extended by these schemes and the study attempt to analyze the motivational factors encouraging investors to prefer post office saving schemes. It also made to examine the rural investors' attitude and awareness towards post office saving schemes in the rural areas of Kerala.

\section{Methods and Materials}

Senthil Kumar and Desti Kannaiah (2014), Mathumitha S (2015) and Ravindran and Venkatachalam (2016) highlighted that postal saving system provide depositors a safe, convenient method to save money and to promote saving among the poor. Kalaraiarasi N and Saranya Devi (2016) analyzed the role of post office in channelizing small savings in rural areas and recommended the option of investing in post office saving scheme like NSC, Indira Vilkas Parts, Kisan Vikas Pasta and Monthly Income Schemes. The study is based on both primary and secondary sources. Primary data were collected from 60 investors and 6 post offices through well-structured questionnaire and interview schedule. Secondary data was collected from various journals, magazines and websites. Sample respondents have been selected from the rural areas of Kasaragod district and are considered for study. 6 post offices, namely Kottamala, West Eleri, Bheemanadi, Kollampara, Plachikkara and Chayyoth were selected and 10 respondents have been selected from each area of the post office.

\section{Results and Discussion}

Post offices are basically classified into head-post offices, sub-post offices including E.D sub-post office and branchpost offices. Kasaragod district has 244 post offices; 2 head post offices, 212 branch post offices and 30 sub-post offices. Out of this, 233 are delivery and 11 non-delivery post offices. So far as the public is concerned, there is basically no difference in the character of the services rendered by subpost offices and head-post offices, except in regard to a few post offices saving bank transaction. Customers enjoy various saving schemes available in the post office that is highly beneficial for the people. 
Table 1: shows various Post Office Saving Schemes (POSS), interest rate, minimum and maximum balance of it.

\begin{tabular}{|c|l|c|c|c|}
\hline S. No. & Name of service & $\begin{array}{c}\text { Interest rates } \\
\text { (in percentage) }\end{array}$ & $\begin{array}{c}\text { Minimum balance } \\
\text { (in rupees) }\end{array}$ & $\begin{array}{c}\text { Maximum balance } \\
\text { (in rupees) }\end{array}$ \\
\hline 1 & Post Office Saving Account & 4 & 50 & 500 \\
\hline 2 & Recurring Deposit Account & 7.1 & Per month & No limit \\
\hline 3 & Time Deposit & 6.8 & 200 & No. limit \\
& & 7.1 & & 4.5 lakh \\
\hline 4 & Monthly Income Scheme & 7.6 & 1500 & No limit \\
\hline 5 & National Saving Certificate /Saving & 7.8 & 100 & No limit \\
\hline 6 & Public Provident Fund & 7.8 & 200 & 15 lakh \\
\hline 7 & Senior Citizen Saving Scheme & 8.3 & 1000 & 1.5 lakh \\
\hline 8 & Sukanya Samriddi Account & 8.6 & 1000 & \\
\hline Source: www.mint research.com
\end{tabular}

Saving and investment are decided by the quantum of income and is influenced by the age of investors. From table.2 it is ascertained that 69 percentages of the investors are 31-60 years of age and males are playing a dominant role in taking investment in post offices; among these 87 percentages are married. Table. 2 also reveals that 33 percentages are below secondary, 37 percentages have secondary, 23 percent possess higher secondary and 7 percent of investors have Graduation and Post-graduation.

Table 2: Age, Sex, Education and Marital status of investors in POSS.

\begin{tabular}{|l|c|l|c|l|l|l|c|}
\hline \multicolumn{2}{|c|}{ Age } & \multicolumn{2}{c|}{ Education } & \multicolumn{2}{c|}{ Sex } & \multicolumn{2}{c|}{ Marital status } \\
\hline Age in Years & $\%$ & Status & $\%$ & Gender & $\%$ & Status & $\%$ \\
\hline $15-30$ & 16 & Below SSLC & 33 & Male & 72 & Married & 87 \\
\hline $31-45$ & 37 & SSLC & 37 & Female & 28 & Single & 13 \\
\hline $46-60$ & 32 & HSC & 23 & Others & 0 & Total & $\mathbf{1 0 0}$ \\
\hline Above 60 & 15 & Degree and PG & 7 & Total & $\mathbf{1 0 0}$ & & \\
\hline Total & $\mathbf{1 0 0}$ & Total & $\mathbf{1 0 0}$ & & & & \\
\hline Source: Primary data
\end{tabular}

The income available for spending after deducting expenditure for necessities or fixed items such as food, cloth, transportation, etc. have greater influence on investment decisions. Table. 3 shows that 33 percent have income level below Rs. 10000, 50 percent in between Rs. 10001-30000, and 10 percent have Rs. 30001-50000 income level.

Table 3: Income of investors in POSS.

\begin{tabular}{|l|c|l|c|}
\hline \multicolumn{2}{|c|}{ Income } & \multicolumn{2}{c|}{ Source } \\
\hline Income level in Rs. & Percentage & \multicolumn{1}{c|}{ Pourcentage } \\
\hline Below 10000 & 33 & Daily wage & 17 \\
\hline $10001-30000$ & 50 & Farmers income & 33 \\
\hline $30001-50000$ & 10 & Govt. Employees income & 8 \\
\hline Above 50000 & 7 & Pensioners & 25 \\
\hline Total & 100 & Professionals & 2 \\
\hline & & Others & 15 \\
\cline { 2 - 4 } & & Total & $\mathbf{1 0 0}$ \\
\hline Source : Primary data & & \\
\end{tabular}

Post offices provided different types of saving schemes like Saving Account, Recurring Deposits, Time Deposit, Monthly Income Scheme, National Saving Certificates, Public Provident Fund, Senior Citizen Saving Account and Sukanya Samriddi Account. Table. 4 shows that 37 percent prefer saving bank account, 23 percent prefer recurring deposit account, 17 percent prefer time deposit, 8 percent prefer senior citizen saving scheme and 7 percent monthly income 
Table 4: Preference of schemes of POSS scheme.

\begin{tabular}{|l|c|}
\hline Preferences & Percentage \\
\hline Post Office Saving Account & 37 \\
\hline Time Deposit & 17 \\
\hline Recurring Deposit & 23 \\
\hline Monthly Income Scheme & 7 \\
\hline National Saving Scheme & 2 \\
\hline Public Provident Fund & 3 \\
\hline Senior Citizen Saving Scheme & 8 \\
\hline Sukanya Samriddhi Accounts & 3 \\
\hline Total & $\mathbf{1 0 0}$ \\
\hline Source: Primary data \\
\hline
\end{tabular}

The level of satisfaction of the basic amenities available in POSS (Table 5) shows that majority are agreed positively.

Table 5: Satisfaction level of basic amenities in POSS.

\begin{tabular}{|l|c|}
\hline Factors & Percentage \\
\hline Parking facilities & 32 \\
\hline Infrastructure facilities & 10 \\
\hline Seating facilities & 17 \\
\hline Adequate facilities & 33 \\
\hline Localities post & 2 \\
\hline $\begin{array}{l}\text { Adequate space in } \\
\text { office }\end{array}$ & 3 \\
\hline Drinking facilities & $\mathbf{1 0 0}$ \\
\hline Total \\
\hline Source: Primary data \\
\hline
\end{tabular}

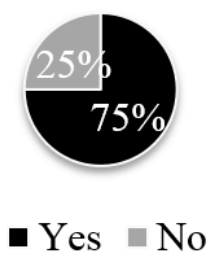

Fig. 1: POSS better than other options.

Post Office Saving Schemes provided various schemes in the rural areas to people for investing their money in post offices. Figure.1 presents that post office saving schemes are better than other options ( 75 percent) and reasons stated are given in Table 6.

Table 6: Reason for POSS better than other schemes.

\begin{tabular}{|l|c|}
\hline Reason & Percentage \\
\hline Safety & 27 \\
\hline Attractive return & 9 \\
\hline Prompt payment & 40 \\
\hline Convenient to operate & 24 \\
\hline Total & $\mathbf{1 0 0}$ \\
\hline Source: Primary data \\
\hline
\end{tabular}

Awareness of the rural people about post office saving schemes presented in table. 7 shows that 33 percent were aware about post office saving account and 15 percent about recurring deposit. 25 percentages are aware of time deposit.

Table 7: Level of awareness about post office saving schemes.

\begin{tabular}{|l|c|}
\hline \multicolumn{1}{|c|}{ Item } & Percentage \\
\hline Post office saving account & 33 \\
\hline Recurring deposit & 15 \\
\hline Time deposit & 25 \\
\hline Monthly income scheme & 5 \\
\hline National saving certificate & 3 \\
\hline Public provident fund & 4 \\
\hline Senior citizen scheme & 8 \\
\hline Sukanya samriddhi account & 7 \\
\hline Total & $\mathbf{1 0 0}$ \\
\hline Source: Primary data \\
\hline
\end{tabular}

Fig. 2: states the factors influencing rural investors to invest amount in post office saving schemes. 25 percentages are highly influenced by the schemes in post offices, 13 percent by the high interest and 7 percent by the tax benefit.

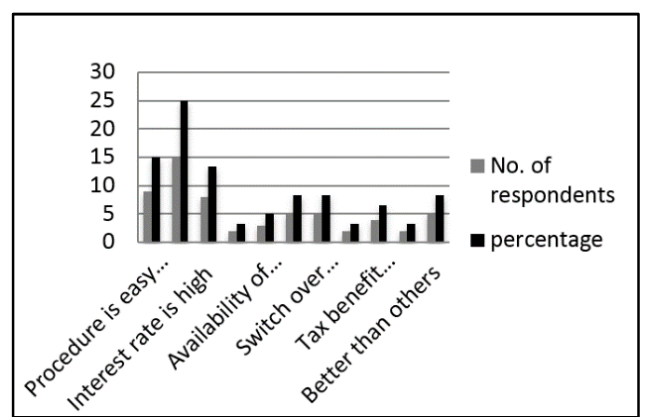

Fig. 2: Motivational factors encouraging investors to prefer POSS.

In post office saving, investors faced lot of problems. Table. 8 states that 25 percentages faced the poor awareness of post office saving scheme, 20 percent respond that agent is not reliable and 8 percent states about the attractiveness of the scheme.

Table 8: Problems faced in depositing POSS.

\begin{tabular}{|l|c|}
\hline \multicolumn{1}{|c|}{ Problems } & Percentage \\
\hline Poor awareness & 25 \\
\hline Delay in processing & 5 \\
\hline Agent not reliable & 20 \\
\hline Low return & 4 \\
\hline High penal charge & 5 \\
\hline No guarantee of return of money & 8 \\
\hline Less attractive & 8 \\
\hline Cumbersome procedure & 5 \\
\hline Lack of information & 20 \\
\hline Total & $\mathbf{1 0 0}$ \\
\hline Source: Primary data \\
\hline
\end{tabular}




\section{Conclusion}

In India, there are various investment schemes and opportunities available for individuals. POSS plays an important role in the development of economy as it offers an opportunity for the poor and people belongs to rural areas to invest in various saving schemes. It connects the rural areas with rest of the country and also provides banking facilities in the absence of banks in rural areas. In rural areas awareness about post office deposits schemes are low and majority aware about saving schemes through agents. Post office therefore, has to re-orient its services and offer better schemes to attract more number of investors.

\section{Source of Funding}

None.

\section{Conflicts of Interest}

None.

\section{Reference}

1. Aggarwal R. "Identify factors influencing preference towards post office saving scheme", Int J Res Manage Technol. 2012;2(6):550-9.
2. Gupta MK, Gupta N. "A study of customer's satisfaction in special reference to service provided by banks and post office in NCR", Int J Multidiscip Res. 2012;2(2):222-34.

3. Kalaraiarasi N, Devi SS. "Depositors satisfaction and level of awareness towards post office saving bank scheme with special reference to Udumalpet", Int J Innov Res Adv Stud. 2016;3(9):227-31.

4. Karthikeyan B. "Small Investors Perception on Post Office Saving Schemes", Unpublished thesis, Madras University: 17.2011.

5. Mathumitha S. "Investors attitude towards post office saving scheme in Cumbum town", Int J Commerce Business Manag. 2015;4(6):798-806.

6. Kanthi PK, Kumar A. "Post office savings and its relevance in rural area with references to Madukkarai block, Coimbatore district”, Int J Sci Res.2013;2(1):27-30.

7. Ravindran G, Venkatachalam V. "Investment opportunities of postal service sectors in India", Int J Adv Res Innov Ideas in Educ. 2016;1(3):226-9.

8. Senthil KK, Kannaiah D. "Investors attitude towards in post office”, Res J Finance Accounting. 2014;5(15):158-75.

How to cite: Karunakaran N, B Athira, Post office savings and attitude of rural investors in Kerala: A study from Kasaragod district. J Manag Res Anal. 2020;7(2):60-3. 